\title{
Analisis Peranan Subsektor Tanaman Pangan terhadap Perekonomian Jawa Barat
}

\author{
Role Analysis of Food Crop Subsector to West Java Economic Development \\ Wilaga Azman Haris ${ }^{1 *}$, Ma'mun Sarma ${ }^{2}$ \& A Faroby Falatehan ${ }^{2}$
}

\begin{abstract}
${ }^{1}$ Program Studi Manajemen Pembangunan Daerah, Institut Pertanian Bogor, J1 Kamper Wing 2 Level 5, Kampus IPB Dramaga Bogor 16680; ${ }^{2}$ Departemen Ekonomi Sumber Daya Lingkungan, Fakultas Ekonomi dan Manajemen, Institut Pertanian Bogor, Jl Kamper Wing 2 Level 5 Kampus IPB Dramaga Bogor 16680;

*Penulis korespondensi.e-mail: wilagaa@gmail.com

(Diterima: 10 Desember 2017; Disetujui: 7 Februari 2018)
\end{abstract}

\begin{abstract}
Agriculture sector plays important role in regional development. Agriculture sector's role involves other sectors such as input provider, feed provider, Gross Domestic Product provider, labor provider, and household income main source. One of agriculture subsector is food crop whereas paddy, corn, and soybean are food crop commodities that have important and stategic roles in development. Their production are targeted to achieve self sufficiency by 2017. The main objective of this research was to analyze the role of food crop subsector to West Java's economy. The specific objective of this research involve output structure analysis, gross added value structure analysis, linkage analysis, and final demand impact analysis. This research employs secondary data. Secondary data used West Java Input-Output Table 2010. Secondary data analysis applies input output anaylisis to answer objective of this research among output structure analysis, gross added value structure analysis, linkage analysis, final demand impact analysis. The results showed that the food crop's output structure and gross value added structure tends to low. Food crop also does not show strong linkage with its upstream sectors and downstream sectors. Final demand impact to output, gross added value, and household income also show that the food sector is low even though the food crop has better ability to absorb labor than of processing industry sector.
\end{abstract}

Keywords: backward linkage, final demand impact analysis, forward linkage, input-output analysis.

\begin{abstract}
ABSTRAK
Sektor pertanian merupakan salah satu sektor yang penting dalam pembangunan. Sektor pertanian utamanya berperan sebagai penyedia bahan baku, penyedia bahan pakan, penyedia bahan baku untuk industri kecil, menengah, dan besar, penyumbang Produk Domestik Regional Bruto (PDRB), penyerap tenaga kerja, dan sumber utama pendapatan rumah tangga. Salah satu subsektor pada sektor pertanian adalah subsektor tanaman pangan. Komoditas yang terdapat pada subsektor tanaman pangan juga memiliki peranan penting dan strategis dalam pembangunan. Komoditas tanaman pangan, khususnya padi, jagung, dan kedelai ditargetkan mencapai swasembada pada tahun 2017. Tujuan utama penelitian ini adalah untuk menganalisis peranan subsektor tanaman pangan dalam perekonomian Jawa Barat. Adapun tujuan spesifik penelitian ini meliputi menganalisis struktur output dan struktur nilai tambah bruto subsektor tanaman pangan, menganalisis keterkaitan subsektor tanaman pangan dengan subsektor lainnya, dan menganalisis dampak permintaan akhir. Data yang digunakan berupa data sekunder. Data sekunder yang digunakan adalah Tabel InputOutput 2010. Analisis data sekunder menggunakan analisis input-output untuk menjawab tujuan
\end{abstract}


penelitian antara lain menganalisis peranan subsektor tanaman pangan, menganalisis keterkaitan subsektor tanaman pangan, dan menganalisis dampak permintaan akhir terhadap perekonomian. Hasil penelitian menunjukkan bahwa kontibusi strukur output, struktur nilai tambah bruto, struktur upah dan gaji dari subsektor tanaman pangan cenderung rendah. Subsektor tanaman pangan juga tidak memiliki keterkaitan yang kuat dengan sektor-sektor hulu dan sektor-sektor hilirnya. Dampak permintaan akhir subsektor tanaman pangan terhadap output, nilai tambah bruto, dan pendapatan rumah tangga juga lebih rendah daripada sektor industri pengolahan. Meski begitu, subsektor tanaman pangan dapat menyerap tenaga kerja lebih baik daripada sektor industri pengolahan.

Kata kunci: analisis input-output, analisis dampak permintaan akhir, keterkaitan ke belakang, keterkaitan ke depan.

\section{PENDAHULUAN}

Hampir separuh penduduk Indonesia, yaitu sebesar 102 juta jiwa, mengalami kekurangan pangan pada tahun 2016. Dua puluh tiga persen dari jumlah penduduk Indonesia menderita sangat rawan pangan, yaitu hanya dapat memenuhi kurang dari $70 \%$ kebutuhan pangannya, sedangkan $27.16 \%$ sisanya hanya dapat memenuhi $70 \%$ hingga $89.9 \%$ dari kebutuhan pangannya. Kondisi kerawanan pangan yang diderita oleh $50.85 \%$ penduduk Indonesia dapat menjadi penyebab kemiskinan dan tidak tercapainya tujuan dari pembangunan (BPS 2017).

Pembangunan untuk mengentaskan kemiskinan masyarakat dilakukan pada sektor perekonomian wilayah. Sektor pertanian merupakan salah satu sektor penting dalam pembangunan ekonomi baik dalam lingkup nasional maupun daerah. Output sektor pertanian berkontribusi dalam berbagai sektor perekonomian, antara lain penyedia bahan pangan, penyedia bahan pakan, bahan baku industri kecil, menengah, hingga besar, penyumbang Produk Domestik Bruto (PDB), penyerap tenaga kerja, dan sumber utama pendapatan rumah tangga pedesaan. Kontribusi sektor pertanian terhadap PDB nasional pada tahun 2017 mencapai 18\% dengan rata-rata pertumbuhan sekitar $9.71 \%$ pada 2012 hingga 2016 (BPS, 2017).

Sektor pertanian merupakan salah satu sektor penting dalam pembangunan ekonomi baik dalam lingkup nasional maupun daerah. Output sektor pertanian berkontribusi dalam berbagai sektor perekonomian, antara lain penyedia bahan pangan, penyedia bahan pakan, bahan baku industri kecil, menengah, hingga besar, penyumbang Produk Domestik Bruto (PDB), penyerap tenaga kerja, dan sumber utama pendapatan rumah tangga pedesaan. Kontribusi sektor pertanian terhadap PDB nasional pada tahun 2017 mencapai 18\% dengan rata-rata pertumbuhan sekitar $9.71 \%$ pada 2012 hingga 2016. (BPS, 2017).

Salah satu subsektor pada sektor pertanian adalah subsektor tanaman pangan. Tanaman pangan menjadi sektor penting dalam pembangunan Indonesia seiring ditetapkannya sasaran utama dari penguatan pasokan pangan dan diversifikasi konsumsi pangan pada pembangunan Indonesia periode 2014 hingga 2019 adalah peningkatan ketersediaan pangan yang bersumber dari dalam negeri untuk komoditas barang pokok, antara lain padi, jagung, dan kedelai. Sasaran utama pembangunan padi adalah meningkatkan jumlah surplus dari produksi dalam negeri. Sasaran utama kedelai adalah meningkatkan produksi terutama untuk mencukupi kebutuhan konsumsi tahu dan tempe. Sasaran utama jagung adalah meningkatkan produksi dalam negeri untuk memenuhi kebutuhan pakan ternak dan dan industri kecil (Bappenas, 2014). Salah satu kebijakan pada Rencana Strategis Kementerian Pertanian 2015-2019 adalah peningkatan swasembada beras dan peningkatan produksi jagung dan kedelai. Beras dan kedelai juga ditetapkan menjadi barang kebutuhan pokok, sedangkan benih padi, jagung, dan kedelai ditetapkan menjadi barang penting berdasarkan 
Peraturan Presiden Republik Indonesia Nomor 71 Tahun 2015. Barang kebutuhan pokok adalah barang yang menyangkut hidup orang banyak dengan skala pemenuhan kebutuhan yang tinggi sedangkan barang penting adalah barang strategis yang berperan penting dalam menentukan kelancaran pembangunan nasional.

Langkah pemerintah dalam menetapkan sektor tanaman pangan menjadi sektor strategis pembangunan dan memiliki sasaran untuk mencapai swasembada salah satunya disebabkan tingginya kebutuhan masyarakat akan tanaman pangan. Hal ini dapat terlihat dari tingkat partisipasi konsumsi beras yang mencapai $99.6 \%$ pada tahun 2014. Tingkat partisipasi konsumsi beras menunjukkan hampir seluruh masyarakat mengonsumsi beras. Tingkat konsumsi beras juga stabil dari tahuntahun sebelumnya yaitu $99.7 \%$ pada tahun 2009 dan $99.6 \%$ pada tahun 2011. Tingkat partisipasi kedelai tinggi seiring kedelai dimanfaatkan dengan produk turunan yang beranaka ragam, antara lain tahu, tempe, dan tauco. Tingkat partisipasi konsumsi jagung rendah disebabkan jagung hanya dikonsumsi secara langsung dalam bentuk jagung pipilan atau jagung dengan kelobotnya. Jagung lebih banyak dimanfaatkan sebagai pakan, sehingga masyarakat mengonsumsi jagung secara tidak langsung melalui ayam, itik, dan telur (BKP 2015).

Selain dikonsumsi secara langsung, rumah tangga mengonsumsi makanan yang dibuat dari bahan baku beras, jagung, dan kedelai secara tidak langsung, yaitu melalui industri pangan. Industri pengolahan menghasilkan output dalam bentuk setengah jadi dan bentuk olahan. Tingkat partisipasi konsumsi jagung rendah, yaitu sebesar $8.6 \%$ pada tahun 2014. Hal ini menunjukkan bahwa industri pengolahan atau industri pangan lebih banyak menyerap hasil produksi untuk diolah menjadi salah satunya pakan. Beras dan kedelai juga diolah melalui industri pengolahan. Industri pengolahan yang menggunakan input beras, jagung, dan kedelai antara lain industri penggilingan dan pembersihan padi-padian dan biji-bijian, industri penggilingan padi dan penyosohan beras, industri penggilingan padi dan pemipilan jagung, industri penggillingan tepung beras dan tepung jagung, industri tempe kedelai, dan industri tahu kedelai (BPS, 2012).

Permintaan beras yang tinggi menyebabkan beras harus tersedia cukup baik secara fisik, sosial, dan ekonomi dari waktu ke waktu. Hal ini dapat menjadi potensi permasalahan apabila ditinjau dari sudut pandang antar pelaku ekonomi. Asumsi produsen atau pedagang yang menghendaki keuntungan sebanyak-banyaknya berseberangan dengan asumsi konsumen yang menghendaki harga semurah-murahnya. Perbedaan asumsi ini dapat menjadi sebab kegagalan pasar, salah satunya inflasi (Mangkoesoebroto, 2000). Pemerintah sebagai salah satu pelaku ekonomi dapat mengantisipasi dan menanggulangi kegagalan pasar yang dapat terjadi seiring posisi strategis tanaman pangan dalam sosial ekonomi penduduk. Salah satu intervensi yang dapat dilakukan untuk menanggulangi inflasi yang disebabkan oleh padi atau beras adalah menjamin ketersediaan (supply) padi atau beras secara terus menerus dari waktu ke waktu. Pemerintah pusat mendorong pemerintah daerah untuk mencapai swasembada beras, jagung, dan kedelai yang diperoleh dari produksi domestik. Adapun sasaran untuk produksi padi tahun 2019 sebesar 82 juta ton, jagung sebesar 24,1 juta ton, dan kedelai sebesar 1.921 ribu ton (Bappenas 2014).

Target swasembada tersebut diperoleh dari produksi di tingkat daerah, yaitu provinsi dan kabupaten/kota. Provinsi Jawa Barat merupakan salah satu daerah sentra produksi padi, jagung, dan kedelai di Indonesia. Provinsi Jawa Barat menempati posisi pertama sebagai daerah produsen padi pada tahun 2013 dan kedua pada tahun 2014 dan 2015. Provinsi Jawa Barat menempati posisi keenam sebagai daerah produsen jagung pada tahun 2013 hingga 2014 dan posisi ketujuh pada tahun 2015. Provinsi Jawa Barat menempati posisi keempat sebagai daerah produsen kedelai pada tahun 2013 dan 2015, dan posisi ketiga pada tahun 2014. Kondisi ini menunjukkan bahwa Jawa Barat merupakan salah satu daerah yang dapat menyangga target swasembada. 
Provinsi Jawa Barat memiliki potensi produksi komoditas tanaman pangan, agroekologi, dan tenaga kerja untuk mencapai tujuan swasembada. Potensi luas panen tanaman pangan di Provinsi Jawa Barat didominasi oleh tanaman padi, yaitu sekitar 2,03 juta hektar dengan produksi 11,37 juta ton pada tahun 2015 . Komoditas padi ditemukan relatif merata di Jawa Barat, baik di daratan rendah, seperti Indramayu, Karawang, Subang, Bekasi, dan Cirebon, maupun di daratan tinggi, seperti Sukabumi, Garut, Cianjur, dan bogor. Provinsi Jawa Barat memiliki curah hujan paling tinggi dan memiliki potensi sumber daya air yang melimpah. Masyarakat yang bekerja di lapangan usaha pertanian sebesar $16.4 \%$ dari total angkatan kerja, atau sebanyak 3,094 orang. Proporsi tenaga kerja di bidang pertanian hampir menyamai sektor industri, walaupun sumbangan PDRB sektor pertanian (7.7\%) lebih kecil daripada sektor industri (43\%) pada tahun 2015. Hal ini menunjukkan bahwa sektor pertanian menjadi sumber mata pencaharian sebagian besar penduduk Jawa Barat.

Kesejahteraan ekonomi merupakan salah satu dimensi pembangunan. Terdapat beberapa pendekatan untuk mengukur kesejahteraan ekonomi di antaranya adalah tingkat output. Tingkat output adalah besaran seluruh nilai transaksi barang dan jasa dari seluruh sektor perekonomian pada suatu wilayah dalam jangka waktu tertentu. Besaran tingkat output dari masing-masing sektor perekonomian dapat dibandingkan. Distribusi output suatu sektor yang relatif tinggi terhadap sektor-sektor lainnya dapat menunjukkan sektor tersebut menjadi tumpuan pembangunan. Meski demikian, tingginya distribusi output suatu sektor belum tentu menjamin kesejahteraan masyarakat pada sektor tersebut. Kesejahteraan masyarakat ditunjukkan dari balas jasa atau nilai tambah terhadap penciptaan output tersebut yang dapat digunakan sebagai disposable income. Oleh sebab itu, ukuran keberhasilan pembangunan pada dimensi ekonomi diukur melalui distribusi output dan distribusi nilai tambah.
Pengelolaan sumber daya pada sektor tanaman pangan menimbulkan interaksi dengan sektor-sektor lainnya. Proses budi daya tanaman pangan membutuhkan input baik dari sektor lain, seperti pupuk, obat-obatan, keuangan, maupun dari sektor tanaman pangan itu sendiri, misalnya benih. Hasil produksi tanaman pangan juga dikonsumsi secara langsung atau tidak langsung melalui proses pengolahan. Padi diolah sektor industri penggilingan menjadi beras giling, beras sosoh, dedak, ketan, dan sekam padi. Jagung diolah sektor industri pengolahan menjadi jagung giling dan jagung sosoh. Kedelai diolah sektor industri menjadi tempe, tahu, ampas tahu, dan ampas tahu. Tanaman pangan menunjukkan sektor tersebut memiliki keterkaitan dengan sektor-sektor, baik sektor hulu maupun sektor hilirnya.

Keterkaitan antara sektor-sektor menyebabkan perubahan permintaan pada sektor-sektor yang saling berinteraksi. Perubahan permintaan akan berdampak pada besar output yang dihasilkan. Perubahan output dapat memengaruhi perubahan balas jasa atas produksi barang dan jasa yang dihasilkan. Perubahan output berasal dari perubahan input produksi. Salah satu input produksi adalah tenaga kerja. Oleh sebab itu, perubahan permintaan dapat berdampak permintaan atas tenaga kerja.

Atas dasar tersebut diatas, tujuan penelitian ini adalah menganalisis peranan, menganalisis keterkaitan subsektor tanaman pangan dengan sektor lainnya, dan menganalisis dampak multiplier yang ditimbulkan dari perubahan permintaan akhir subsektor tanaman pangan terhadap sektor perekonomian Jawa Barat.

\section{METODOLOGI}

\section{Jenis dan Sumber Data}

Data yang digunakan dalam penelitian ini menggunakan data sekunder, yaitu Tabel InputOutput Jawa Barat 2010. Data sekunder bersumber dari Badan Pusat Statistik Provinsi Jawa Barat. Pengolahan data dilakukan dengan bantuan program Microsoft Excel 2007. 


\section{Metode Analisis Data}

Alat analisis yang digunakan untuk mempelajari peranan subsektor tanaman pangan terhadap sektor-sektor lainnya adalah Tabel Input-Output. Tabel input-output Jawa Barat 2010 diagregrasi dari semula 86 sektor dengan matriks 86x86 menjadi 10 sektor dengan matriks 10x10 yang terdiri dari sektor (1) tanaman pangan; (2) pertanian, peternakan, kehutanan, dan perikanan; (3) pertambangan dan penggalian; (4) industri pengolahan; (5) listrik, gas, dan air bersih; (6) bangunan/konstruksi; (7) perdagangan, hotel, dan restoran; (8) pengangkutan dan komunikasi; (9) keuangan, persewaan, dan jasa perusahaan dan (10) jasajasa.

Langkah selanjutnya adalah membuat persamaan Input Output sesuai dengan data yang tersedia. Persamaan Tabel Input-Output disajikan pada persamaan berikut ini.

$$
\begin{aligned}
& z_{11}+z_{12}+z_{13}+\cdots+z_{110}+Y_{1}=X_{1} \\
& z_{21}+z_{22}+z_{23}+\cdots+z_{210}+Y_{2}=X_{2} \\
& \vdots \\
& z_{101}+z_{102}+z_{103}+\cdots+z_{1010}+Y_{10}=X_{10}
\end{aligned}
$$

Atau dapat ditulis kembali dengan persamaan berikut.

$\sum_{j=1}^{10} z_{i j}+Y_{i}=X_{i}$ untuk $\mathrm{i}=1,2, \ldots, 10 \ldots(1)$

$\mathrm{Z}_{\mathrm{ij}}$ adalah banyaknya output sektor I yang digunakan sebagai input oleh sektor $\mathrm{j}, \mathrm{Y}_{\mathrm{i}}$ adalah permintaan akhir terhadap sektor $\mathrm{I}$, dan $\mathrm{X}_{\mathrm{i}}$ adalah total output sektor i. Jika diketahui koefisien teknis $a_{i j}$ dengan rumus seperti berikut:

$$
a_{i j}=\frac{z_{i j}}{X_{j}}
$$

apabila persamaan 2 diubah menjadi $z_{i j}=$ $a_{i j} X_{j}$, maka persamaan 1 dapat ditulis ulang dalam sistem persamaan berikut

$$
\begin{array}{r}
X_{1}-a_{11} X_{1}-a_{12} X_{2}-a_{13} X_{3}-\cdots \\
-a_{110} X_{10}=Y_{1}
\end{array}
$$

$$
\begin{gathered}
X_{2}-a_{21} X_{1}-a_{22} X_{2}-a_{23} X_{3}-\cdots \\
-a_{210} X_{10}=Y_{2} \\
\vdots \quad \\
X_{10}-a_{101} X_{1}-a_{102} X_{2}-a_{103} X_{3}-\cdots \\
-a_{1010} X_{10}=Y_{10}
\end{gathered}
$$

atau disederhanakan menjadi

$$
\begin{gathered}
\left(1-a_{11}\right) X_{1}-a_{12} X_{2}-a_{13} X_{3}-\cdots \\
-a_{110} X_{10}=Y_{1} \\
-a_{21} X_{1}+\left(1-a_{22}\right) X_{2}-a_{23} X_{3}-\cdots \\
-a_{210} X_{10}=Y_{2} \\
\vdots \\
-a_{101} X_{1}-a_{102} X_{2}-a_{103} X_{3}-\cdots+(1 \\
\left.-a_{1010}\right) X_{10}=Y_{10}
\end{gathered}
$$

dan dapat disederhanakan menjadi notasi sebagai berikut.

$(I-A) X=Y \ldots(3)$

yang mana I adalah matriks identitas berukuran $10 \times 10$, A merupakan matriks koefisien input, sedangkan $\mathrm{X}$ dan $\mathrm{Y}$ masing-masing menunjukkan vektor kolom matriks ouput dan permintaan akhir. Persamaan matriks 3 dapat kita ubah bentuknya menjadi:

$X=(I-A)^{-1} Y$

Persamaan 4 menjadi persamaan yang digunakan untuk menghitung analisis peranan, keterkaitan, dan dampak.

Analisis peranan antar sektor bertujuan melihat kontribusi sektor tanaman pangan dalam keseluruhan perekonomian. Kontribusi sektor tanaman pangan diukur dari struktur output ( $\left.\mathrm{D}_{\mathrm{O}}\right)$ dan struktur Nilai Tambah Bruto ( $\left.\mathrm{D}_{\mathrm{NTB}}\right)$. Struktur output pada seluruh sektor digunakan untuk melihat kontribusi tanaman pangan terhadap seluruh barang dan jasa yang diproduksi dalam satuan waktu Tabel InputOutput dibuat. Hasil perhitungan $\mathrm{D}_{\mathrm{o}}$ kemudian diberi peringkat, yaitu peringkat 1 untuk sektor dengan nilai output tertinggi. Hal ini menunjukkan bahwa sektor yang menempati peringkat 1 dapat dikatakan sebagai sektor unggulan karena sektor tersebut paling banyak diproduksi oleh kegiatan perekonomian. 
Demikian pula dengan $\mathrm{D}_{\mathrm{NTB}}$. $\mathrm{D}_{\mathrm{NTB}}$ dihitung untuk melihat sektor mana yang menghasilkan balas jasa tertinggi. $\mathrm{D}_{\mathrm{NTB}}$ kemudian juga disusun berdasarkan peringkat dari $\mathrm{D}_{\mathrm{NTB}}$ yang tertinggi hingga terkecil. Sektor dengan $\mathrm{D}_{\text {NTB }}$ tertinggi merupakan sektor yang menghasilkan manfaat dari kegiatan perekonomian. Perhitungan $D_{0}$ terdapat pada persamaan 5 dan perhitungan $\mathrm{D}_{\mathrm{NTB}}$ terdapat pada persamaan 6.

$$
\begin{aligned}
& D O=\frac{X_{i}}{\sum_{i=1}^{10} X i} \ldots(5) \\
& D N T B=\frac{v_{i}}{\sum_{i=1}^{10} v_{i}} \ldots
\end{aligned}
$$

Model I-O dapat digunakan sebagai alat pengambil keputusan sektor-sektor mana saja yang berperan sebagai leading sector dalam pembangunan ekonomi. Suatu sektor dikatakan sebagai leading sector apabila sektor tersebut memiliki kemampuan daya sebar dan kepekaan yang sangat tinggi dalam suatu perekonomian, sehingga efek yang diberikan ganda. Di satu sisi sektor tersebut dapat mendorong permintaan agregat (aggregate demand) yang lebih tinggi dan di sisi lain bisa meningkatkan penawaran agregat (aggregate supply) untuk pemenuhian kebutuhan dalam negeri. Analisis keterkaitan terdiri dari keterkaitan suatu sektor dengan sektor hulu dan/atau hilirinya dan kemampuan suatu sektor menggerakan seluruh perekonomian. Rumus yang dapat digunakan untuk analisis keterkaitan menggunakan metode Rasmussen. Metode Rasmussen menganalisis keterkaitan ke belakang atau backward linkage (BL) dengan menjumlahkan baris dari matriks teknologi dan menganalisis keterkaitan ke depan atau forward linkage (FL) dengan menjumlahkan kolom dari matriks teknologi. Adapun rumus yang digunakan untuk melihat keterkaitan antar sektor adalah sebagai berikut.

$$
\begin{aligned}
& B L_{j}^{R}=\sum_{i=1}^{10} g_{i j} \ldots(7) \\
& F L_{j}^{R}=\sum_{j=1}^{10} g_{i j}
\end{aligned}
$$

dimana $B L_{j}^{R} \quad$ menunjukkan ukuran keterkaitan ke belakang dan $F L_{j}^{R}$ menunjukkan keterkaitan ke depan. $g_{i j}$ menunjukkan elemen pada matriks invers Leontief, $G=(I-A)^{-1}$. Oleh karena metode Rasmussen menggunakan matriks invers Leontief, maka ukuran keterkaitan antara sektor yang diperoleh dapat dikatakan merupakan ukuran keterkaitan langsung dan tidak langsung, yang menghitung dampak total dari suatu sektor dalam perekonomian. Dengan kata lain, suatu sektor menjadi leading sector ketika nilai $B L_{j}^{R}$ dan $F L_{j}^{R}$ tinggi.

Metode Rasmussen juga dapat melihat bagaiamana suatu sektor menggerakkan seluruh sektor perekonomian. Hal ini dilihat dari daya penyebaran (power of dispersion) dan derajat kepekaan (sensitivity of dispersion). Kemampuan penyebaran dan kepekaan penyebaran diukur dengan menggunakan rumus sebagai berikut.

$$
\begin{aligned}
& \alpha_{j}=\frac{\sum_{i=1}^{10} g_{i j}}{\frac{1}{10} \sum_{i} \sum_{j} g_{i j}} \ldots(9) \\
& \beta_{i}=\frac{\sum_{j=1}^{10} g_{i j}}{\frac{1}{10} \sum_{i} \sum_{j} g_{i j}} \ldots(10)
\end{aligned}
$$

dimana $\alpha_{j}$ menunjukkan indeks daya penyebaran dari sektor $j$ dalam perekonomian, $\beta_{i}$ merupakan indeks derajat kepekaan dari sektor $i$, dan $g_{i j}$ adalah elemen pada matriks invers Leontief, $G=(I-A)^{-1}$.

Daya penyebaran dan derajat kepekaan merupakan perbandingan dampak, baik ke belakang maupun ke depan, terhadap rata-rata seluruh dampak sektor, sehingga nilai masingmasing sering disebut sebagai backward linkage effect ratio dan forward linkage effect ratio. Jika nilai indeks daya penyebaran sektor $j$ lebih besar dari satu, $\alpha_{j}>1$, maka secara relatif permintaan akhir sektor $j$ dalam merangsang pertumbuhan produksi lebih besar dari rata-rata, sehingga sektor ini merupakan sektor yang strategis dalam memacu pertumbuhan ekonomi. Demikian pula untuk sektor $i$ yang mempunyai 
indeks derajat penyebaran lebih besar dari 1, $\beta_{i}>1$, maka sektor tersebut dapat digolongkan sebagai sektor strategis, karena secara relatif sektor tersebut dapat memenuhi permintaan akhir sebanyak di atas kemampuan rata-rata dan sektor lainnya.

Analisis dampak dilakukan untuk melihat perubahan output, pendapatan, dan tenaga kerja yang terjadi pada sektor perekonomian terhadap permintaan akhir. Rumus yang digunakan dalam menganalisis analisis dampak multiplier tersebut sebagai berikut.

$$
\begin{aligned}
& \Delta X=(I-A)^{-1} F d \\
& \Delta N T B=\mu_{n+1}(I-A)^{-1} F d \\
& \Delta L=\omega_{n+1}(I-A)^{-1} F d \\
& \Delta I=\alpha_{n+1}(I-A)^{-1} F d
\end{aligned}
$$

dimana $\Delta X$ adalah dampak permintaan akhir terhadap pembentukan output, $\triangle N T B$ adalah dampak permintaan akhir terhadap nilai tambah bruto, $\Delta I$ adalah dampak permintaan akhir terhadap pendapatan rumah tangga, $\Delta L$ adalah dampak permintaan akhir terhadap penyerapan tenaga kerja, $F d$ adalah permintaan akhir, $(I-A)^{-1}$ adalah matriks kebalikan Leontief, $\mu_{n+1}$ adalah koefisien nilai tambah bruto, $\omega_{n+1}$ adalah koefisien tenaga kerja, dan $\alpha_{n+1}$ adalah koefisien pendapatan. $\mathrm{V}_{\mathrm{j}}$ adalah nilai tambah bruto pada sektor $\mathrm{j}, \mathrm{L}_{\mathrm{j}}$ adalah jumlah tenaga kerja pada sektor $\mathrm{j}$, dan $\mathrm{W}_{\mathrm{i}}$ adalah besarnya pendapatan pada sektor i. Koefisien tersebut diperoleh dengan rumus berikut.

$$
\begin{aligned}
& \mu_{n+1}=\frac{\sum_{j=1}^{10} V_{j}}{X_{j}} \\
& \omega_{n+1}=\frac{L_{i}}{X_{i}} \\
& \alpha_{n+1}=\frac{W i}{X_{i}}
\end{aligned}
$$

\section{HASIL DAN PEMBAHASAN}

\section{Struktur Output}

Output adalah nilai seluruh produk, baik barang atau jasa, yang dihasilkan oleh sektorsektor produksi dengan memanfaatkan faktor produksi yang tersedia di daerah. Telaahan besarnya output yang tercipta pada masingmasing sektor dapat memberi gambaran sektor mana yang dapat menjadi leading sector. Berdasarkan agregasi 10 sektor, terlihat bahwa lima sektor yang memberikan kontribusi output sektor terbesar antara lain sektor industri pengolahan ( $\mathrm{Rp} 792.65$ triliun atau memberikan andil setengah dari seluruh output), sektor perdagangan, hotel, dan restoran $(\mathrm{Rp} 235.51$ triliun atau $15.14 \%$ ), sektor jasa-jasa (Rp 113.30 triliun atau $7.28 \%$ ), sektor pengangkutan dan komunikasi (Rp 102.87 triliun atau $6.61 \%)$, dan sektor bangunan/konstruksi (Rp 94.03 triliun atau 6.05 $\%)$. Sektor tanaman pangan menempati urutan keenam atau sebesar Rp 60.76 triliun atau menyumbang $3.91 \%$ output.

\section{Struktur Nilai Tambah Bruto}

Nilai tambah bruto adalah balas jasa terhadap faktor produksi yang tercipta karena adanya kegiatan produksi. Nilai tambah bruto dirinci menurut upah dan gaji, surplus usaha, penyusutan, dan pajak tak langsung. Hasil analisis menunjukkan lima sektor dengan nilai tambah bruto tertinggi terdapat pada sektor industri pengolahan $(\mathrm{Rp} 290.75$ triliun atau menyumbang $37.73 \%$ dari seluruh nilai tambah bruto yang tercipta), sektor perdagangan, hotel, dan restoran (Rp 172.71 triliun atau $22.41 \%$ dari seluruh nilai tambah bruto), sektor jasa-jasa (Rp 68.31 triliun atau $8.86 \%$ ), sektor pengangkutan dan komunikasi (Rp 54.63 triliun atau 7.09\%), dan sektor pertanian, peternakan, kehutanan, dan perikanan ( $\operatorname{Rp} 53.99$ triliun atau $7.01 \%)$. Sektor tanaman pangan menempati urutan keenam yaitu sebesar Rp 43.20 triliun atau $5.61 \%$. Hasil ini menunjukkan sektor industri memberikan manfaat terbesar sebagai balas jasa proses produksi barang atau jasa. Di sisi lain, tanaman pangan belum menjadi sektor unggulan 
yang dapat memberikan manfaat sebagai balas jasa kegiatan produksi.

\section{Forward Linkage dan Backward Linkage Sektor Tanaman Pangan}

Besaran keterkaitan ke depan langsung dan tak langsung suatu sektor menunjukkan pengaruh tidak langsung dari kenaikan permintaan akhir satu unit sektor tertentu yang dapat meningkatkan total output seluruh sektor perekonomian. Parameter ini menunjukkan kekuatan suatu sektor dalam mendorong peningkatan seluruh sektor perekonomian, baik yang terkait dengan hulu maupun yang terkait hilirnya. Sektor dengan keterkaitan paling tinggi berarti memiliki potensi menghasilkan output produksi yang tinggi pula. Besarnya keterkaitan ke depan langsung dan tak langsung ditunjukkan dengan Forward Linkage (FL). Besarnya keterkaitan ke belakang langsung dan tak langsung ditunjukkan dengan indeks Backward Linkage (BL). Besar BL dan FL terdapat pada Tabel 1.

Tabel 1. Backward linkage dan forward linkage sektor perekonomian Jawa Barat

\begin{tabular}{lll}
\hline Sektor & BL & FL \\
\hline Tanaman Pangan & 1,551 & 1,180 \\
Pertanian, Peternakan, Kehutanan, dan Perikanan & 1,278 & 1,422 \\
Pertambangan dan Penggalian & 1,475 & 1,376 \\
Industri Pengolahan & 6,012 & 2,299 \\
Listrik, Gas, dan Air Bersih & 1,338 & 2,226 \\
Bangunan/konstruksi & 1,218 & 2,549 \\
Perdagangan, hotel, dan restoran & 1,105 & 1,546 \\
Pengangkutan dan Komunikasi & 1,428 & 2,010 \\
Keuangan, Persewaan, dan Jasa Perusahaan & 1,337 & 1,580 \\
Jasa-Jasa & 1,318 & 1,874 \\
rata-rata & 1,806 & 1,806 \\
\hline
\end{tabular}

Hasil perhitungan menunjukkan indeks BL dan FL tertinggi terdapat pada sektor industri. BL dan FL sektor industri jauh melampaui rata-rata $\mathrm{BL}$ dan FL seluruh sektor. Artinya, sektor industri menjadi leading sector karena dapat menarik sektor hulu dan mendorong sektor hilirnya sangat baik. Hal ini konsisten dengan hasil analisis sektor industri pada pembahasan sebelumnya bahwa kontribusi output sektor industri pada seluruh perekonomian merupakan yang terbesar.

Sektor-sektor lainnya yang dapat mendorong sektor hilir lebih baik dari rata-rata antara lain sektor listrik, gas, dan air bersih, sektor bangunan/konstruksi, sektor pengangkutan dan komunikasi, dan sektor jasajasa. Sektor-sektor tersebut efektif menjadi input bagi sektor-sektor hilirnya. Tidak ada sektor yang efektif menarik sektor hulunya dibanding sektor industri pengolahan. Indeks BL seluruh sektor kecuali sektor industri pengolahan berada di bawah rata-rata. Sektor tanaman pangan tidak efektif menarik sektor hulu dan mendorong sektor hilirnya karena indeks BL dan FL sektor tanaman pangan di bawah rata-rata.

\section{Daya Penyebaran dan Derajat Kepekaan}

Model I-O dapat menjelaskan seberapa jauh tingkat hubungan atau keterkaitan antar sektor perekonomian. Keterkaitan antara sektor perekonomian dapat berupa hubungan ke depan (forward linkage) dan hubungan ke belakang (backward linkage). Hubungan ke depan atau daya penyebaran berkaitan dengan penjualan barang jadi. Hubungan ke belakang atau derajat kepekaan berkaitan dengan bahan mentah atau bahan baku. Besarnya daya penyebaran dan derajat kepekaan ditunjukkan dengan indeks. Indeks daya penyebaran dan indeks derajat kepekaan dapat digunakan untuk penentuan sektor-sektor kunci yang dapat dikembangkan untuk pembangunan.

Adapun sektor yang memiliki indeks daya penyebaran dan indeks derajat kepekaan lebih dari satu menunjukkan bahwa sektor tersebut memiliki daya penyebaran atau derajat 
kepekaan yang di atas rata-rata. Indeks daya penyebaran dan indeks derajat kepekaan sektor perekonomian Jawa Barat ditunjukkan pada Tabel 2.

Tabel 2. Indeks daya penyebaran dan indeks derajat kepekaan Jawa Barat

\begin{tabular}{lll}
\hline Sektor & $\begin{array}{l}\text { Indeks } \\
\text { Penyebaran (DP) }\end{array}$ & $\begin{array}{l}\text { Indeks } \\
\text { Kepekaan (DK) }\end{array}$ \\
\hline Tanaman Pangan & 0.65 & 0.86 \\
Pertanian, Peternakan, Kehutanan, dan Perikanan & 0.79 & 0.71 \\
Pertambangan dan Penggalian & 0.76 & 0.82 \\
Industri Pengolahan & 1.27 & 3.33 \\
Listrik, Gas, dan Air Bersih & 1.23 & 0.74 \\
Bangunan/konstruksi & 1.41 & 0.67 \\
Perdagangan, hotel, dan restoran & 0.86 & 0.61 \\
Pengangkutan dan Komunikasi & 1.11 & 0.79 \\
Keuangan, Persewaan, dan Jasa Perusahaan & 0.87 & 0.74 \\
Jasa-Jasa & 1.04 & 0.73 \\
\hline
\end{tabular}

Sektor yang memiliki keterkaitan ke sektorsektor hilirnya di atas rata-rata meliputi sektor industri pengolahan, sektor listrik, gas, dan air bersih, sektor bangunan/konstruksi, sektor pengangkutan dan komunikasi, dan sektor jasajasa. Sektor-sektor yang memiliki keterkaitan ke sektor-sektor hulunya di atas rata-rata adalah sektor industri pengolahan.

Hasil perhitungan indeks daya penyebaran dan indeks derajat kepekaan dapat dikelompokkan menjadi 4 kelompok, yaitu kelompok 1 adalah sektor-sektor yang mempunyai indeks daya penyebaran dan indeks derajat kepekaan relatif tinggi (diatas rata-rata), kelompok 2 adalah sektor-sektor yang mempunyai indeks derajat kepekaan tinggi (di atas rata-rata), tetapi daya penyebarannya rendah (di bawah rata-rata), kelompok 3 adalah sektor-sektor yang mempunyai indeks daya penyebaran dan indeks derajat kepekaan relatif rendah, dan kelompok 4 adalah sektor-sektor yang mempunya indeks daya penyebaran tinggi (di atas rata-rata), tetapi indeks derajat kepekaan rendah (di bawah rata-rata). Sektor yang termasuk pada kelompok 1 hanya sektor industri pengolahan. Sektor yang termasuk pada kelompok 2 meliputi sektor listrik, gas, dan air bersih, sektor bangunan/konstruksi, sektor pengangkutan dan komunikasi, dan sektor jasajasa. Sektor yang termasuk kelompok 3 meliputi sektor tanaman pangan, sektor pertanian, peternakan, kehutanan, dan perikanan, sektor pertambangan dan penggalian, sektor perdagangan, hotel, dan restoran, dan sektor keuangan, persewaan, dan jasa perusahaan.

\section{Dampak Permintaan Akhir terhadap Output}

Output sektor tanaman pangan yang terbentuk sebagai akibat dari konsumsi rumah tangga sebesar Rp 50.11 triliun, pengeluaran pemerintah sebesar $\mathrm{Rp} 2.96$ triliun, pembentukan modal tetap bruto sebesar $\mathrm{Rp}$ 15.75 triliun, perubahan stok sebesar Rp 10.59 triliun, ekspor sebesar Rp 41.59 triliun. Permintaan akhir sektor tanaman pangan berkontribusi menyumbang $6 \%$ dari seluruh sektor atau sebesar Rp 122.01 triliun.

Konsumsi rumah tangga mengakibatkan pembentukan output sektor tanaman pangan sebesar Rp 50.11 triliun, output sektor pertanian, peternakan, kehutanan, dan perikanan $\mathrm{Rp} 79.78$ triliun, output sektor pertambangan dan penggalian $\mathrm{Rp} 28.52$ triliun, output sektor industri pengolahan sebesar Rp 626.78 triliun, output sektor listrik, gas, dan air bersih sebesar Rp 40.45 triliun, output sektor bangunan/konstruksi sebesar Rp 6.70 triliun, output sektor perdagangan, hotel, dan restoran sebesar Rp 20.70 triliun, output sektor pengangkutan dan komunikasi sebesar Rp 64.37 triliun, output sektor keuangan, persewaan, dan jasa perusahaan sebesar Rp 20.98 triliun, dan output sektor jasa-jasa sebesar Rp 42.53 triliun. Jumlah konsumsi rumah tangga sebesar $\mathrm{Rp}$ 980.96 triliun menunjukkan besarnya output 
seluruh sektor yang terbentuk sebagai akibat dari konsumsi rumah tangga. Konsumsi rumah tangga merupakan komponen yang paling tinggi dalam memengaruhi pembentukan output di masing-masing sektor diantara pengeluaran pemerintah, pembentukan modal tetap, perubahan stok, dan ekspor. Pesatnya dampak output yang tercipta harus dibarengi dengan sistem distribusi output yang efektif (Mary et al, 2012).

\section{Dampak Permintaan Akhir terhadap Nilai Tambah Bruto}

Nilai Tambah Bruto (NTB) adalah input primer yang merupakan bagian dari input secara keseluruhan. Hubungan antara NTB dengan output bersifat linear. Artinya, kenaikan atau penurunan output akan diikuti secara proporsional oleh kenaikan dan penurunan NTB. Nilai Tambah Bruto termasuk faktor eksogen yang memengaruhi faktor endogen (output) masing-masing sektor.

Nilai Tambah Bruto sektor tanaman pangan yang terbentuk sebagai akibat dari konsumsi rumah tangga sebesar $\mathrm{Rp} 44.52$ triliun, konsumsi pemerintah sebesar Rp 2.63 triliun, pembentukan modal tetap bruto sebesar Rp 13.99 triliun, perubahan stok sebesar $\mathrm{Rp} 9.41$ triliun, dan ekspor sebesar Rp 37.84 triliun. Jumlah konsumsi rumah tangga dari seluruh sektor sebesar Rp 453.28 triliun atau sebesar $46.71 \%$ dari seluruh sektor menunjukkan besarnya konsumsi rumah tangga merupakan komponen yang paling tinggi dalam memengaruhi penciptaan Nilai Tambah Bruto di masing-masing sektor. Sektor industri pengolahan merupakan sektor terbesar dalam penciptan nilai tambah yaitu mencapai $54.89 \%$ atau Rp 532.63 triliun. Sektor tanaman pangan menempati posisi kedua yaitu sebesar $11.17 \%$ atau Rp 108.41 triliun. Sektor tanaman pangan memiliki kemampuan menciptakan nilai tambah bruto setelah industri pengolahan.

Konsumsi rumah tangga menyebabkan penciptaan Nilai Tambah Bruto sektor tanaman pangan sebesar Rp 44.52 triliun, Nilai Tambah Bruto sektor pertanian, peternakan, kehutanan, dan perikanan sebesar Rp 63.15 triliun, Nilai
Tambah Bruto sektor pertambangan dan penggalian sebesar Rp 22.83 triliun, Nilai Tambah Bruto sektor industri pengolahan $\mathrm{Rp}$ 229.91 triliun, Nilai Tambah Bruto sektor listrik, gas, dan air bersih sebesar Rp 1.08 triliun, Nilai Tambah Bruto sektor bangunan/konstruksi sebesar Rp 2.07 triliun, Nilai Tambah Bruto sektor perdagangan, hotel, dan restoran sebesar Rp 15.18 triliun, Nilai Tambah Bruto sektor pengangkutan dan komunikasi sebesar Rp 34.18 triliun, Nilai Tambah Bruto sektor keuangan, persewaan, dan jasa perusahaan sebesar Rp 14.67 triliun, dan sektor jasa-jasa Rp 25.64 triliun. Demikian pula pada komponen permintaan akhir yang lain.

\section{Dampak Permintaan Akhir terhadap Kebutuhan Tenaga Kerja}

Tenaga kerja merupakan salah satu faktor produksi yang penting. Tenaga kerja dapat mempengaruhi besarnya output dan permintaan akhir Oleh sebab itu, permintaan akhir dapat memberikan dampak terhadap kebutuhan tenaga kerja. Perhitungan dampak permintaan akhir terhadap kebutuhan tenaga kerja dilakukan dengan mengukur koefisien tenga kerja. Koefisien tenaga kerja tanaman pangan sebesar 0.048. Hal ini berarti bahwa untuk menghasilkan satu triliun rupiah output di sektor tanaman pangan diperlukan 0.048 tenaga kerja. Hasil analisis koefisien tenaga kerja dapat dimanfaatkan untuk daya serap tenaga kerja di masing-masing sektor. Semakin tinggi koefisien tenaga kerja di suatu sektor menunjukkan semakin tinggi pula daya serap tenaga kerja di sektor yang bersangkutan, karena semakin banyak tenaga kerja yang dibutuhkan untuk menghasilkan satu triliun output.

Hasil kali matriks koefisien tenaga kerja dengan dampak output menghasilkan dampak permintaan akhir terhadap kebutuhan kerja. Permintaan akhir pada sektor tanaman pangan menginduksi penyerapan tenaga kerja sebanyak 5.916 .578 orang atau sebesar $29 \%$ dari penyerapan tenaga kerja seluruh sektor. Jumlah ini merupakan jumlah terbesar diantara sektor lainnya. Induksi penyerapan tenaga kerja sektor industri pengolahan hanya sebesar 5.630.376 
orang atau 28\%. Sektor pertanian, peternakan, kehutanan, dan perikanan dan sektor jasa-jasa merupakan sektor yang menginduksi penyerapan tenaga kerja terbesar selanjutnya, yaitu berturut-turut 2.652 .575 orang (13\%) dan 2.588.010 orang (13\%). Kemampuan sektor tanaman pangan dalam penyerapan tenaga kerja juga secara empiris telah ditunjukkan oleh penelitian Astrini (2013) yang menyatakan bahwa meskipun sektor pertanian tidak menjadi leading sector pada struktur output dan keterkaitan antara sektor hulu dan hilir, sektor pertanian memiliki keunggulan dalam penyerapan tenaga kerja yang dapat dimanfaatkan menjadi peningkatan kesejahteraan masyarakat.

Kebutuhan tenaga kerja sektor tanaman pangan hampir menyamai penyerapan tenaga kerja pada sektor industri walaupun terdapat perbedaan antara output sektor tanaman pangan dengan sektor industri. Hal ini mengindikasikan sektor tanaman pangan dapat menjadi leading sector dalam penyerapan tenaga kerja. Tenaga kerja yang besar seyogyanya juga dapat menghasilkan output yang bersaing dengan sektor lainnya pula.

\section{Dampak Permintaan Akhir terhadap Pendapatan Rumah Tangga}

Pendapatan rumah tangga merupakan salah satu parameter keberhasilan pembangunan. Proporsi peningkatan pendapatan sektor tanaman pangan sebesar $6.39 \%$ dari seluruh sektor. Sektor industri pengolahan merupakan sektor penyumbang proporsi peningkatan pendapatan rumah tangga tertinggi dengan 52.25\%, diikuti oleh sektor pertanian, peternakan, kehutanan, dan perikanan sebesar $8.17 \%$. Sektor tanaman pangan menempati posisi ketiga teratas setelah sektor pertanian, peternakan, kehutanan, dan perikanan. Pemerintah dapat menunjuk instansi yang dapat menjadi fasilitator pemasaran hasil pertanian. Peran instansi ini di antaranya adalah menciptakan rantai tata niaga yang efektif sehingga pendapatan rumah tangga yang dapat diterima oleh pekerja menjadi lebih besar (Abas et a,. 2013). Peranan sektor tanaman pangan terhadap pendapatan rumah tangga dapat meningkat dari waktu ke waktu seiring dengan pengelolaan distribusi yang lebih baik (Hartono et al, 2015).

\section{KESIMPULAN DAN SARAN}

Hasil penelitian menunjukkan tanaman pangan bukan menjadi leading sector pembangunan perekonomian Jawa Barat. Analisis peranan menunjukkan sektor yang menjadi leading sector adalah industri pengolahan, yang ditunjukkan distribusi terbesar dari struktur output dan nilai tambah bruto. Sedangkan, nilai sektor tanaman pangan terdapat di peringkat 6 pada struktur output dan peringkat 5 pada struktur nilai tambah bruto. Secara lebih terperinci, sektor industri pengolahan lebih memberikan manfaat kepada masyarakat daripada sektor tanaman pangan. Proporsi upah dan gaji pada sektor industri pengolahan lebih besar daripada proporsi upah dan gaji pada sektor tanaman pangan. Sektor industri pengolahan mendominasi indeks keterkaitan, antara lain backward linkage, forward linkage, daya penyebaran, dan derajat keterkaitan. Sektor tanaman pangan berada di bawah rata-rata sektor lainnya. Hasil analisis dampak menunjukkan sektor industri yang memberikan distribusi yang dominan. Meski begitu, kemampuan sektor tanaman pangan dalam menyerap tenaga kerja hampir menyamai kemampuan sektor industri.

Sektor tanaman pangan dapat menjadi leading sector dalam hal penyerap tenaga kerja. Potensi ini dapat dimanfaatkan menjadi pondasi kesejahteraan masyarakat yang merata. Seyogyanya, pembangunan sektor tanaman pangan diarahkan kepada pertumbuhan output. Hal ini sejalan dengan Peraturan Menteri Pertanian Republik Indonesia Nomor 03 Tahun 2015 yang menetapkan padi, jagung, dan kedelai mencapai swasembada. Pertumbuhan output seyogyanya dicapai seiring dengan pemerataan. Pertumbuhan output tidak mencapai sasaran kesejahteraan masyarakat secara luas apabila hanya sebagian masyarakat saja yang dapat mengakses pertumbuhan output tersebut. 
Sementara itu, kondisi saat ini pembangunan sektor tanaman pangan lebih dinikmati sebagai surplus usaha. Oleh sebab itu, kebijakan hingga program pemerintah, seperti subsidi, lebih diarahkan kepada rumah tangga pertanian dengan lahan gurem agar dapat memeroleh lahan yang dapat mencapai skala usaha.

\section{UCAPAN TERIMA KASIH}

Ucapan terima kasih disampaikan kepada Badan Perencanaan Pembangunan Daerah Jawa Barat, Pusat Data Penelitian dan Pengembangan Jawa Barat, dan Badan Pusat Statistik Jawa Barat untuk bantuannya kepada peneliti dalam pengumpulan data.

\section{DAFTAR PUSTAKA}

Astrini, U. R. (2013). Analisis Revitalisasi Sektor Pertanian dalam Pembangunan terhadap Perekonomian di Jawa Timur Melalui Pendekatan Input-Output. Jurnal Ekonomi Pembangunan, 2(3), 159-174.

Badan Pusat Statistik. (2017). Statistik Indonesia 2017.

Badan Pusat Statistik Provinsi Jawa Barat. (2013). Tabel Input-Output Provinsi Jawa Barat Tahun 2010.

Badan Ketahanan Pangan. (2015). Direktori Perkembangan Konsumsi Pangan. Jakarta: Badan Ketahanan Pangan.

Capone, R., Bilali, H. E., Debs, P., Cardone, G., \& Driouech, N. (2014). Food System Sustainability and Food Security: Connecting the Dots. Journal of Food Security, 2(1), 13-22.

Daryanto, A. \& Hafizrianda, Y. 2010. Analisis Input-Output dan Social Accounting Matrix untuk Pembangunan Ekonomi Daerah. Bogor: IPB Press.

Kementerian Perencanaan Pembangunan Nasional/ Badan Perencanaan Pembangunan Nasional. (2014). Rencana Pembangunan Jangka Menengah Nasional 2015 -2019.
Novita, D., Rahmanta, \& Mahalli, K. (2009). Dampak Investasi Sektor Pertanian terhadap Perekonomian Sumatera Utara (Pendekatan Analisis Input-Output). Jurnal Perencanaan dan Pengembangan Wilayah, 4(3), 131-141.

Razak, M. I. M., Hamzah, A. S. M. A., Abas, N., Idris, R., \& Ibrahim, Z. 2013. Sustaining Food Production for Food Security in Malaysia. Journal of Economics and Development Studies, 1(2), 19- 25.

Rustiadi, E., Saefulhakim. S., \& Panuju. D. R. (2011). Perencanaan dan Pengembangan Wilayah. Jakarta: Yayasan Pustaka Obor Indonesia, 249-264.

Saravia-Matus, S. L., Paloma, S. G., \& Mary, S. (2012). Economics of Food Security: Selected Issues. Bio-based and Applied Economics, 1(1), 65-80

Sukanto, D. G. T. (2011). Analisis Peranan Sektor Pertanian terhadap Perekonomian Jawa Tengah (Pendekatan Analisis InputOutput). Jurnal Ekonomi dan Bisnis, 1(2), 13-25.

Suryantini, A., Hartono, S., Nurhayati A, \& Widyaningsih, W. (2015). Peran Sektor Pertanian terhadap Perekonomian Daerah Istimewa Yogyakarta. Jurnal Social Economic of Agriculture, 4(1), 1-13.

Wijaya, I. R. A., Masyhuri, Irham, \& Hartono, S. (2014). Analisis Input Output Pengolahan Tembakau di Provinsi Jawa Timur. Agro Ekonomi, 24(1), 1-9. 